Marquette University

e-Publications@Marquette

$10-1-1997$

Labor, the Law, and Economics: The Organization of the Chicago Flat Janitors' Union, 1902-1917

John Jentz

Marquette University

Accepted version. Labor History, Vol. 38, No. 4 (Fall 1997): 413-431. DOI. C 1997 Taylor \& Francis (Routledge). Used with permission. 


\title{
Labor, the Law, and Economics: The Organization of the Chicago Flat Janitors' Union, 1902-1917
}

\author{
John B. Jentz \\ Raynor and Memorial Libraries, Marquette University \\ Milwaukee, WI
}

\begin{abstract}
The researching and writing of this essay was supported in part by the Service Employees International Union. In 1921 the Chicago Flat Janitors' Union became Local 1 of the new Building Service Employees' International Union, the predecessor of the SEIU. The conclusions expressed by the author do not necessarily represent the views of the SEIU. This essay has profited from critical readings by James R. Grossman, Bruce C. Nelson, Steven Rosswurm, and Richard Schneirov.
\end{abstract}

The explanatory power of the law in interpreting American labor history is the subject of a lively academic debate. Legal historians have used the law and the judicial system as the locus for studying the relationship between the labor movement and the state. When these scholars analyze the late nineteenth and early twentieth centuries, they focus on the emergence of business unionism in the American Federation of Labor with its distinctive policy of political voluntarism. Business unionism saw power on the shop floor as the main source of labor's strength, while pursuing a politics of advantage within the two party system. These scholars' main line of argument stresses how the distinctive power and policy of the American legal system pushed the labor movement toward business unionism by judicial undermining of labor's political successes, by insulating the chief definer of public labor policy, the courts, from political influence, and by defining the thought of labor leaders in legalistic terms. This whole body of scholarship raises questions about what else the law might explain in

Labor History, Vol. 38, No. 4 (Fall, 1997): pg. 413-431. DOI. This article is (c) Taylor \& Francis (Routledge) and permission has been granted for this version to appear in e-Publications@Marquette. Taylor \& Francis (Routledge) does not grant permission for this article to be further copied/distributed or hosted elsewhere without the express permission from Taylor \& Francis (Routledge). 
American labor history, and some scholars argue that the law is the critical factor in defining the larger contours of the whole subject. ${ }^{1}$

Labor historians tend to welcome this scholarship's emphasis on labor's relation to politics and the state, while being divided about what the law actually explains. David Brody and Melvyn Dubofsky have been particularly skeptical of claims about the law as the decisive factor in American labor history, stressing instead the larger structures of economic and particularly political power within which both the law and the labor movement operated. Thisessay supports Brody and Dubofsky's line of reasoning, while arguing that the whole discussionof labor and the law pays too little attention to the role that unions played in the economy. Closer attention to the economic function of unions would help delineate the parameters of the law's influence on labor, while, incidentally, broadening the definition of business unionism. ${ }^{2}$

The history of the Chicago Flat Janitors' Union provides a case study of how the law impacted unskilled workers organizing under the auspices of the AFL during the progressive era. Despite legal attacks by employers, the janitors formed a union with the active support of both the Chicago Federation of Labor and several of its constituent unions, particularly the teamsters. Critical to the union's success was its hard-won control of the metropolitan labor market in janitors for apartment buildings. This organizational success gave it the power to negotiate a city-wide contract with the largest umbrella organizations of building owners. The larger owners saw in the union, not simply a threat, but also an opportunity to stabilize the real estate industry by taking wages out of competition. These more substantial players used the annual labor contracts to increase predictability and consolidate their strong position in a chaotic industry with thousands of owners, the great majority of them small to medium-sized. The smaller owners tended to see only a threat in the union, and they provided the main constituency for organizations that attacked it in the courts. The union's organizational power, its stabilizing role in the real estate industry, and divisions about it among the owners were indispensable to its ability to survive repeated legal assaults.

Chicago janitors formed their first locals in 1902 as part of a huge organizing campaign that had begun in the late 1890s under the leadership of the recently founded Chicago Federation of Labor. Rising 
with this tide, janitors' unions formed in apartment buildings and in the office buildings in the downtown business district, the "Loop." There were also locals of elevator operators, window washers, and janitors in public buildings. A flat janitors' local had a black recording secretary and a black business agent, reflecting a policy of organizing interracial locals followed by the janitors throughout their early history. ${ }^{3}$ Other locals were composed exclusively of women, particularly cleaning women in public buildings. So successful was this early campaign that the American Federation of Labor chartered an international union of building service workers in March 1904, the core of which was formed by the Chicago janitors, the strongest of whom were in the Loop office buildings. ${ }^{4}$ The AFL was under considerable pressure from the left to show that it could organize unskilled workers, and the janitors appeared to be a model in which "federated" locals of the unskilled could coalesce into new internationals. ${ }^{5}$

This first international union had a short, factious history. The AFL's national officers constantly had to address conflicts over jurisdiction and mediate disputes among leaders. Within a year and a half the president, Charles Fieldstack, and the international secretary had each called rival conventions in different Illinois cities. Samuel Gompers asked Thomas Kidd, an AFL vice president based in Chicago, to investigate. Kidd concluded that Fieldstack was a "cheap grafter" and the secretary wanted "to be the whole thing." In frustration and disgust the AFL Executive Council revoked the international's charter in the fall of 1905, calling the formation of the international "premature." Overly anxious to show that unskilled workers could really organize under its auspices, the AFL itself had been premature in issuing a charter. ${ }^{6}$

The AFL Executive Council hoped that the fledgling building service locals might thrive without the international, but they withered instead when an aggressive open shop drive stalled the dynamism of the Chicago labor movement. Central to the employers' success was a huge and brutal Chicago teamsters' strike in 1905, during which fourteen people were killed and hundreds injured. Because the teamsters stopped deliveries to struck buildings, their support was critical to the janitors' organizing efforts. The teamsters played a similar critical role for other Chicago unions, among them the 
teachers. Thus when the teamsters were defeated the whole local movement suffered, including the janitors. ${ }^{7}$

The flat janitors' most important early leader, William F. Quesse, left the city after the defeats of 1905, seeking to support his family in rural America, first in Florida and then in Oklahoma. By 1912, however, when he was thirty-four, Quesse and his family were back in the city; and he was again organizing flat janitors. Although it is uncertain when and how he resolved to build another janitors union, it is clear that his commitment energized a small group of about seven leaders who had remained in the city after the first organizing effort. Some of them were still involved in the two surviving, but listless, flat janitors locals then existing in Chicago. (The officers of one of these locals would later challenge Quesse's leadership of the new union.) Quesse and the other leaders organized a third local, receiving a federal charter from the AFL as Federal Local 14332 in October $1912 .^{8}$

Led by Quesse, this new organizing effort was, in his words, "not a spontaneous and overnight affair," but rather "a long thought-of plan." ${ }^{9}$ At its core was cooperation with other unions. Quesse and his compatriots joined, and relied heavily on, the Chicago Federation of Labor and the Illinois Federation of Labor. They reached an accommodation with the building trades, which were jealous that the janitors not violate their jurisdictions. Quesse's union fought for contracts that prohibited janitors from doing painting, carpentry, plumbing, and electrical work. Janitors also asked to see the union cards of building tradesmen working in their buildings. ${ }^{10}$ Most important, the leaders also built an indispensable alliance with the teamsters, in part by helping them with their business. The milk wagon drivers, for example, were paid by commission. The janitors helped them keep track of customers who moved away and alerted the drivers to potential new customers who moved in. ${ }^{11}$ The janitors also protected the markets of businesses that honored their pickets by preventing service by other employers, a policy that also helped cooperating teamsters keep their jobs. ${ }^{12}$

The "long thought-of plan" called for the union to focus on the janitors in the city's widely scattered apartment buildings, most of which were owned by thousands of small to modest-sized proprietors. They did not organize in the Loop where the concentration of janitors in large office buildings would seemingly make forming a union easier. 
An incident involving a janitor named Hartman illustrated why Quesse and his fellows saw an opportunity in the residential sector of the industry.

Gus Anderson, one of the early leaders, remembered that Quesse was again in the city working as a janitor when Hartman was fired "because of some trivial matter." Hartman told Quesse about it, and Quesse went to the offices of the renting agent for Hartman's building, presenting himself as the spokesman for the janitors union. He threatened a strike against all the buildings managed by the agent if Hartman were not rehired, and he was to "avoid trouble." 13 A bluff, since the union was still just a gleam in the eye of a handful of men, Quesse's threat worked because of the stakes involved for the renting agent. If Hartman was a typical janitor, he serviced several buildings to support his family. ${ }^{14}$ The renting agent faced the possibility of inconveniencing the tenants in all his buildings just because of a dispute over a fraction of one janitor's job. It was not worth it. This calculation of costs by the employer turned a problem for the union into an opportunity. The problem was that organizing janitors with numerous employers was costly: typically the union had to reach several agreements just to service one member. The opportunity was that the employer's small stakes in any one janitor's time meant that they would frequently capitulate, as had Hartman's.

The Hartman incident proved catalytic. According to Anderson, it was "an incentive for Mr. Quesse to start a strong organization." ${ }^{15}$ It was also an illustration of why the strategy of organizing in the neighborhoods might work. The central goal of the whole organizing effort was a closed shop. That is, Quesse and the other leaders wanted all flat janitors in one huge local and an agreement with the owners recognizing their union as the sole bargaining agent for janitors and committing employers to hire only members of their organization. This was a common goal for unions in the city, especially in the building trades, whose labor agreements often served as models for the janitors. ${ }^{16}$ From this position of power the leaders could bargain to change the debasing conditions under which janitors worked. The union's ability to change those conditions was the main rationale for its existence. ${ }^{17}$

The leaders' first-hand experience of janitorial work made them tenacious organizers. Wives, and sometimes children, had to do 
janitorial work. Wives were even expected to come to job interviews to see if they were strong enough for the tasks, since employers were actually purchasing the family's labor. The janitors were enraged at these practices, which they considered symbols of a status so low that they were not expected to have normal family lives. The janitor's children were also considered unworthy to associate with those of the tenants, a class prejudice that affected the janitor's whole family. ${ }^{18}$ The basement apartments that the janitors received as part of their pay were damp and dingy. In 1914 the Chicago Department of Health even considered the typical janitor's flat a "nuisance and menace to the other occupants of the building." On call day and night, the janitor had no time for family life. He was expected to take orders, not only from the building owner but also from the tenants, who considered themselves his bosses too. All of these bosses demanded that he do an endless variety of tasks for a pittance, requiring the janitor to service numerous buildings to sustain his family. When Quesse called these conditions a "disgrace to civilization," he meant not only the janitors' low wages but also the lowly class position experienced in encounters between children. ${ }^{20}$ Having been a janitor himself, Quesse understood and articulated the resentment created by class prejudice as well as by low wages and dingy apartments.

Between 1912 and 1915 the leaders of the union executed their plan in grinding, day-today organizing, supported mainly by themselves. The early leaders "beat rugs, washed windows, sold newspapers and did other odd jobs to get a little cash to push the campaign along. Meetings were held over saloons, where rent was free, because some of the boys bought an occasional beer." 21 They obtained free circulars from a friendly printer, and even free legal aid from an attorney named Daniel Cruice, services they dearly needed when they got in fights that landed them in jail. Quesse's son remembered that,

We never knew whether he would come back altogether or in pieces. He came home many a time with marks of one kind and another on his person. Sometimes he didn't come home for awhile because he was locked up in jail for putting a picket on a scab building. ${ }^{22}$

One of those times occurred in December 1912, two months after Local 14332 had been chartered by the AFL. Two building owners, not the police, forced Quesse to the local police station, where 
he was charged with "intimidation" and "preventing the owner or possessor of property of its lawful use and management." He was held in jail for three days, then released after posting a bond of $\$ 500$. Such friendliness of the police and courts for the building owners would be evident again and again in the union's history. In this instance, however, Quesse successfully countersued, winning a settlement of $\$ 10,000$ in damages after an extended court battle. ${ }^{23}$ Encounters with the police and courts were part of everyday life for an organizer.

A strike in 1914 and an associated injunction against the union in 1915 illustrated both the union's organizing tactics and the legal environment in which unions operated. As in the Hartman case, smaller building owners usually signed the union's labor agreement; and those who resisted typically gave in after a janitors' strike and boycott of deliveries. Several of these combination strikes and boycotts were underway against a few buildings almost all the time, sustained by the union's paid pickets and the great majority of union members who were still working. (Serving as a picket was an entrylevel job for many of the union's leaders.) When employers resisted, the issue was usually over the union's demand that only union janitors be hired, not over wages and working conditions. The owners' anger was articulated by the Apartment Buildings Association, which in November 1914 worked to make the strike and boycott against the buildings of Virginia Marshall and her husband a test case for the whole city. ${ }^{24}$ The lawyer representing the Association and the Marshalls was Dudley Taylor, who remained an enemy of the Flat Janitors until his death in $1924 .{ }^{25}$

The conflict began when the Marshalls replaced a union janitor who had resigned with a non-union man. The Marshalls claimed the right to hire whomever they found most qualified, union or not. On November 23, 1914, three union men showed up in the basement of the Marshalls' building at Sheridan Road and Airdrie Place and told Peter Assem, the non-union janitor, that he " 'had better pull out these fires and get out of the building or pay eighteen dollars and get into the union by to-morrow morning; if not, we will get you and make trouble around the building.'" The next day three men returned. Learning that Assem had not complied, they said, "'Well, we will do ours then.'"26 
Pickets appeared, usually in pairs, walking slowly up and down in front of the building, watching and noting every delivery. These were the union's paid pickets. ${ }^{27}$ The pickets arrived at five or six o'clock in the morning and stayed into the early evening, long enough to confront all attempted deliveries. Constantly under surveillance, the tenants became annoyed and fearful, partly because of the violence they associated with labor conflicts in the city. ${ }^{28}$ The wife of Peter Assem, the non-union janitor, had an altercation with a picket while she was cleaning windows, that is, violating the union's ban on janitors' wives doing janitorial work.

"The picket called to me and said, 'You had better quit scabbing if you know what's good for yourself." I was on the front porch at the time and he was walking along slowly on the sidewalk .... . He looks at me in a very ugly manner and if looks could kill a person I would have been dead and buried long ago.'"29

As the strike wore on the pickets came into conflict with the police and private guards hired by the Marshalls. The pickets were accused of "lounging in the street after being ordered to move on" and taken to court. Prepared for such incidents, the union's lawyers demanded jury trials, which the Marshalls considered fruitless to pursue. Some cases, usually involving disorderly conduct, were simply dismissed by the judge. Harassment and arrest of the pickets by the police and private guards was an everyday occurrence. ${ }^{30}$

Supported by the Apartment Buildings Association, the Marshalls continued to resist. One by one, the union called out its janitors in the Marshalls' four nearby buildings. One of the union janitors was Sam McCurdy, a black man, whom the Marshalls replaced with two nonunion blacks. ${ }^{31}$ The pickets effectively stopped all deliveries of ice, coal, groceries, laundry, beer, and milk. This boycott was sustained by the unionization of the city's teamsters and their solidarity with the janitors. Any businessman relying on the teamsters feared being shut down if he forced his drivers to cross the picket lines. An ice dealer told a tenant, " 'If we should deliver ice to you to-day by next Monday we would not have a wagon on the street."'32 The ice dealers had decided as a group to stay away from the struck buildings, for fear of trouble with their drivers. ${ }^{33}$ The milk wagon drivers were the most reliable in their support of Local 14332, which was why they, alone 
among the other unions, were named in the subsequent injunction against the janitors.

Sympathetic neighbors and sympathetic union members throughout the city also sustained the boycott. One tenant tried to circumvent the boycott of milk deliveries by having her friend in a nearby building order milk for her. When the grocery delivery boy found out about it, he told the union picket, who had the supply of extra milk stopped with the cooperation of the milk wagon driver. ${ }^{34}$ Businessmen who were not dependent on teamsters hesitated to make deliveries for fear of "social ostracism" by the janitors and members of other unions. The same fear of social ostracism enforced solidarity among union janitors, some of whom did not want to quit when the union called them out of one of the Marshalls' buildings. ${ }^{35}$

As the strike and boycott extended into December 1914 the union turned to sabotage. When union representatives called a janitor out of a building in December, the representative left the door of the furnace open so coal gases would fill the building. Refuse from the street was dumped into the vestibules of several buildings, and "stink bombs" were thrown. These were "fragile bottles containing a vile smelling substance" which, when broken in halls and vestibules, filled the building with nauseating fumes and odors. ${ }^{36} \mathrm{C}$. E. Van Driesche, a union picket, told one of the Marshalls' private guards that " the union just wants to show them that if there are 20 men around watching they can get in anyhow.'"37 They were reminding the owners that their large investment was vulnerable. They were also practicing strongarmed tactics that had been common in the Chicago labor movement for decades, particularly in the construction trades. These kinds of tactics, combined with similar ones by employers--private arrests of trade unionists, assault committed by hired guards--helped put the courts into the middle of labor-management conflict in Chicago. ${ }^{38}$

Aided by the Apartment Buildings Association, the Marshalls applied for and got a sweeping injunction against the union, issued by Judge Dennis Sullivan on January 27, 1915. ${ }^{39}$ Hostile to labor, Sullivan would remain an enemy of the Flat Janitors through the 1920s, like the Marshalls' lawyer Dudley Taylor. Sullivan copied almost all of the language of his injunction from Taylor's submissions to the court. The injunction stopped every form of organizing engaged in by the union, 
prohibiting it from picketing, boycotting, or striking any of the Marshalls' buildings. Neither could it engage in these activities against businesses servicing their property. It also could not distribute any literature describing the Marshalls or the businesses serving them as "unfair" to union labor. This injunction was typical in an era when judges intervened consistently and pervasively against unions, particularly when their activities involved sympathy strikes, boycotts, and demands for union recognition. Such activities and goals implied collective, class-based initiatives obnoxious to most judges and to the individualist values encoded in the law. ${ }^{40}$

The Sullivan Injunction held more than local interest: in March 1915 AFL president Samuel Gompers requested a copy. ${ }^{41}$ Not long before, Gompers had declared the Clayton Anti-Trust Act, passed in 1914 during Woodrow Wilson's first administration, to be the "Magna Carta of Labor." Supposedly, the law lessened judicial interference in labor affairs by limiting the use of both the antitrust laws and injunctions against unions, but it contained loopholes. The Sullivan Injunction illustrated that Gompers was overly optimistic. ${ }^{42}$ It was in fact part of a storm of injunctions and conspiracy charges against Chicago unions. Within a year of Sullivan's decision the Chicago Federation of Labor had to set up a special legal department to deal with "contempt cases, conspiracy frame-ups and dynamite plots charged against the strikers" in practically every labor conflict. ${ }^{43}$

Sweeping as it was, however, the Sullivan Injunction, which focused on union tactics, did not discuss the central issue between the Flat Janitors' Union and the Marshalls. Examining that issue helps explain the nature of the union's opponents, including divisions among them which the union exploited to win its city-wide victory two years later in January 1917. In their application for an injunction the Marshalls claimed that "it is the policy of the said Janitors' Union to secure a monopoly of the employment of janitors in Chicago" and that it had "combined and conspired" to achieve this goal by compelling all janitors to join the union and all employers to hire only union members. ${ }^{44}$ This was true, and the central issue, although the union would never accept the language of either "monopoly" or "conspiracy" because of the legal freight these terms carried. The Flat Janitors were pursuing a closed shop, which they perceived as a legitimate goal for a

Labor History, Vol. 38, No. 4 (Fall, 1997): pg. 413-431. DOI. This article is (c) Taylor \& Francis (Routledge) and permission has been granted for this version to appear in e-Publications@Marquette. Taylor \& Francis (Routledge) does not grant permission for this article to be further copied/distributed or hosted elsewhere without the express permission from Taylor \& Francis (Routledge). 
legal organizing effort, despite the law's typical hostility to both their goal and their tactics.

The Marshalls experienced the union's effort to control the Chicago labor market in janitors as a tyrannical limitation of their freedom, a violation of their rights, and a threat to their livelihood. They thought the Flat Janitors' Union similarly threatened all owners of apartment buildings in Chicago. ${ }^{45}$ In stark contrast, the janitors experienced the conditions under which they lived and worked as tyrannical, even comparing it to slavery. Gaining control of their sector of the labor market was a precondition for their exercise of freedom-to liberate themselves from intolerable circumstances. The freedom of each individual to choose so valued by the Marshalls was subordinate for the janitors to their freedom to improve their lives. The janitors drew on the labor movement's collective definition of freedom that made trade unions indispensable agents for the workers' exercise of their rights in an industrial society dominated by corporate power. ${ }^{46}$

These conflicting conceptions of freedom and rights were evident in an altercation Quesse had with A. B. Matthews, head of the Apartment Buildings Association. Matthews argued that Mr. Marshall had "exercised his right, . . . , to employ whom he chose and that the Union had no right to interfere. Mr. Quesse said they had a right to interfere and that they had a grievance against Mr. Marshall because of it." 47 The concrete right Quesse claimed was to define the rules under which janitors lived and worked. He felt the union had a legitimate right to "interfere" in the labor market to gain this end. Quesse's sense of his union's rights utilized an "alternative legal language" defined by American labor leaders in the early twentieth century to help them fight the hostile legal environment in which they operated. Their version of the American constitutional tradition claimed for "workers collective action" the same "presumption of legitimacy and social worth" granted by the law to corporations. ${ }^{48}$ Quesse acted on the belief that his union had a right to bargain collectively with employers, even though the law recognized no such right; and he used the legalistic language of rights and grievances to articulate his position.

The conception of absolute individual freedom and rights expressed by the Marshalls and the Apartment Buildings Association was felt most intensely by the small real estate owners. Although the permission for this article to be further copied/distributed or hosted elsewhere without the express permission from Taylor \& Francis (Routledge). 
large owners would acknowledge everything the Marshalls said, they acted to manipulate the housing market in a way analogous to Local 14332 's struggle to control the labor market in janitors. The large owners, too, felt that they had a right to "interfere." One way to promote their position was to protect themselves against the competition of owners who charged lower rents, but protected their profits by cutting wages to service personnel like janitors. For these very reasons a building owner took the union's side in a legal battle during the mid 1920s-- after a city-wide labor agreement had been in place for years. The union's opponents, this owner argued, "did not feel disposed to pay the scale" of wages in the city-wide labor agreement; "I am on the side representing capital, but I believe in being fair to everyone, . . . many Chicago property owners are glad to receive the increased rentals, but would like to keep the janitor's wage as low as possible." 49 A strong union able to enforce its labor agreement would protect owners such as this one from the competition of other property owners who wanted to increase profits by lowering wages. About the same time Oscar Nelson, vice president of the Chicago Federation of Labor, argued that the "average investor in real estate" realized that the Flat Janitors' Union "has stabilized the real estate market."50

If the union were strong enough to enforce a standard wage in the Chicago housing industry, some owners, especially the large ones, might see an advantage for them in the union. In turn, their organizations could help the union influence owners whom it could not sign up, as well as enforce an agreement on those it could. Colin Gordon has analyzed such mutual interests:

In certain circumstances, employers found that the organizational benefits of unionization outweighed its material and managerial costs, that unions and union wages could serve as an important regulatory mechanism. Employers and workers alike saw unionization as a means of regulating labor costs across an industry." 51

Such possibilities for mutual accommodation were strong in this case because the Chicago real estate industry was locally controlled and operating in a metropolitan market. The Chicago and Cook County Real Estate Boards were the predominant organizations of building owners. Together the two Boards represented up to eighty percent of 
the building owners who employed flat janitors. ${ }^{52}$ It really was feasible for these large organizations of property owners to shape the course of their industry, just as it was feasible for one union local to control the metropolitan labor market in janitors for apartment buildings.

Realizing such possibilities for an accommodation with the owners required that the union reach its goal of actually organizing the city's flat janitors. The Sullivan injunction simply made this goal more costly, not impossible. While stopping the strike against the Marshalls, the injunction did not prevent the union from organizing building by building in the neighborhoods, as it had been doing since 1912 . When the injunction was issued in January 1915, the union probably had around 3,000 members. Within two years it doubled that number, making it the dominant force in the labor market for flat janitors, even if it had not organized absolutely all of them. ${ }^{53}$

On its way to toward representing all flat janitors Local 14332's leadership consolidated its own internal position and eliminated rival unions. It was challenged internally during the fall of 1915, nine months after the Sullivan injunction and just as it was on the verge of success following three years of organizing.

Kaspar Thegen had been president of one of the two unions of flat janitors in Chicago when Local 14332 was chartered in 1912. When Quesse's local appeared capable of organizing the whole city, Thegen, now a member of Local 14332, led a rival slate of candidates for union office against Quesse and his core group of leaders. In a request for a court injunction, Thegen claimed that he and his fellow candidates had been kept off the ballot and expelled from the union in violation of its constitution; he also said they had been beaten up and forcibly ejected from a meeting by "sluggers" hired by the union. Thegen's group got its injunction from Judge Dennis Sullivan, ran for office, and lost. ${ }^{54}$ Quesse's group probably thought of its challengers as the surreptitious representatives of a rival organization, Thegen's old local, trying to steal the new union. At about the same time the core leadership also opposed the Janitors' Benefit and Protective Association, which claimed to be only a benevolent society, not a union. Employers used it to show that Local 14332 was not the only union of flat janitors in the city. Local 14332 picketed the building where its president worked until he was either fired by his employer or he resigned from his organization. 55

Labor History, Vol. 38, No. 4 (Fall, 1997): pg. 413-431. DOI. This article is (c) Taylor \& Francis (Routledge) and permission has been granted for this version to appear in e-Publications@Marquette. Taylor \& Francis (Routledge) does not grant permission for this article to be further copied/distributed or hosted elsewhere without the express permission from Taylor \& Francis (Routledge). 
By late 1916--after four years of organizing and associated legal battles--Local 14332 was in a position to bid for its first city-wide contract. Previously the union had held discussions with the Real Estate Boards, even as early as 1912, but reached no binding citywide agreements. On December 1, 1916, the Flat Janitors' Union announced to the building owners and the press that it was seeking a new labor agreement and asked the Real Estate Boards to open negotiations. Perhaps still flushed with its victory in obtaining the Sullivan Injunction, the Apartment Buildings Association convinced the Boards, as well as several smaller groups of owners, not to respond. The Association argued that it had "practically broken up the Janitor's Union." Quesse considered the Association to be a group "of crooks organized for the sole purpose of opposing the janitors union," and one of his goals became to exclude it from any negotiations. ${ }^{56}$

In response to the rebuff by the owners, the union's leaders asked for and received an overwhelming vote from the membership approving a strike. Next they drew up their own labor agreement, including a wage scale based on the highest paid sector of the industry--the Loop office buildings. Then they printed 20,000 copies of this agreement and sent it to all the city's building owners and to the press. They announced that the union would begin working under this agreement on January 15, 1917.57

Throughout the rest of December 1916 and into January 1917 the union worked furiously to sign up individual building owners to that agreement, while masterfully playing to the press. Gus Anderson remembered telling a newspaper reporter that if the Chicago Real Estate Board did not sign the agreement with the union "a general strike on all the buildings controlled by its members would be called." The "10,000 members" of the union could "tie up this town tighterthan a drum," and, in the dead of winter, "a million dollars worth of flat buildings will freeze up." Actually, the union had around 6,000 members and never had any intention of calling a general strike, which would bankrupt it and bring in the courts and police. But, "a good bluff," it "went over with a bang." 58

The Tribune, among other papers, took the story seriously, publishing pictures of tenants earnestly preparing to man boilers in preparation for the strike. In frequent interviews with reporters Quesse fanned these fears while never committing the union to a strike. 
Meanwhile the union called selective strikes against individual buildings, as it had been doing for years. Supported by the teamsters, these strikes were usually successful. Even threats from the Apartment Buildings Association that the teamsters would be indicted on charges of criminal conspiracy did not stop them from honoring the janitors' pickets. ${ }^{59}$

The Real Estate Boards reconsidered negotiating with the union. Quesse agreed, but only if the Apartment Building Association was excluded, which it was. Then the Boards wanted to bring in the State Board of Arbitration to settle the dispute. On January 16th Quesse refused, saying that it was too late: the union had been trying to get negotiations going for weeks but was rebuffed. Now a strike was on, and the Boards' current proposal was inadequate because it did not sufficiently address working conditions. Quesse's confidence derived from the union's success with the Boards' own members; he claimed to have already signed three-quarters of them. Negotiations continued. 60

Then it was Quesse's turn to be surprised. The Boards proposed tying the amount of wages to the rents paid in the buildings. In the past the union had sought to tie wages to the size of the buildings serviced, which meant that union janitors throughout the city made the same wages for the same work. But rents, of course, varied considerably for the same-sized buildings, depending largely on their location. Owners in less desirable areas complained that they paid the same wages as owners who had more income from the same types of property. According to Quesse

they proposed a wage scale based on the income of the apartments, which the Committee of the Union asked for time to consider. Our Committee adjourned to its headquarters and after a careful study decided that the wage scale based on income was possible, provided we could get anywhere near a fair share of the income as compensation for our work. ${ }^{61}$

They could not, however, agree on the "fair share," and left its resolution up to subsequent arbitration. Nonetheless, this "sliding scale," the tying of wages to rents, had been agreed upon. The fact that the Boards even proposed it meant they had decided to accommodate themselves to the union and then use the agreement to

Labor History, Vol. 38, No. 4 (Fall, 1997): pg. 413-431. DOI. This article is (c) Taylor \& Francis (Routledge) and permission has been granted for this version to appear in e-Publications@Marquette. Taylor \& Francis (Routledge) does not grant permission for this article to be further copied/distributed or hosted elsewhere without the express permission from Taylor \& Francis (Routledge) 
NOT THE PUBLISHED VERSION; this is the author's final, peer-reviewed manuscript. The published version may be accessed by following the link in the citation at the bottom of the page.

meet their own needs. The union had, in turn, decided to compromise its previous principle of equal pay for equal work in order to get an accord.

With this kind of accommodation on both sides, an agreement fell into place. The janitors received a wage increase averaging about seven percent; the union had originally asked for ten. The sliding scale was applied to buildings where apartment rents averaged sixty-five dollars per month or above. Wages in buildings below that average were determined by the size of the facilities. Working conditions were improved substantially, beginning with a ban on wives performing janitorial work. Special conditions were defined for notification when janitors quit or were fired. Janitors were to take orders from one person. They could not be required to do work performed by other unions, which mainly affected the building trades. Most important, the union got a closed shop: only members of Local 14332 could be hired, which, among other things, meant the end of any rival union. Disputes about the agreement were to be submitted to arbitration by a committee composed of members appointed by each side, a mechanism that had been in proposed agreements since the first unsuccessful organizing campaign fifteen years previously. The oneyear agreement would be open for renegotiation on December 31, 1917.

This contract defined the terms of debate about the flat janitors' labor agreements for at least the next decade. It had been achieved with less than 100 janitors striking out of a membership of $6,000 .^{62}$

The scope of Local 14332's achievement stood out in sharp contrast to the simultaneous defeat of the office janitors. Chartered only the year before, Office Janitors' Local 15155 demanded a wage increase and a closed shop in January 1917, in the midst of the flat janitors' battle. When the powerful Loop real estate interests-organized in the Building Managers Association--refused, Local 15155 took its members out on strike. Accusations of strong-armed tactics flew from both sides. The strike collapsed after six weeks, despite the active support of the Chicago Federation of Labor and other unions. The office janitors suffered from inexperienced and ineffective leadership, evidenced by the replacement of their president during the strike. They had demanded higher wages in a sector of the industry already paying the highest rates in the city; their wage scale had even

Labor History, Vol. 38, No. 4 (Fall, 1997): pg. 413-431. DOI. This article is (c) Taylor \& Francis (Routledge) and permission has been granted for this version to appear in e-Publications@Marquette. Taylor \& Francis (Routledge) does not grant permission for this article to be further copied/distributed or hosted elsewhere without the express permission from Taylor \& Francis (Routledge) 
been the basis of the flat janitors' first contract proposals. The office janitors had also taken on the city's most powerful real estate interests without first building up an adequate base of power, as the Flat Janitors' Union had done by organizing in the neighborhoods. The office janitors were so badly beaten that their local had to merge with another to salvage what remained of their organization. ${ }^{63}$

The Chicago Flat Janitors Union organized a huge local of unskilled workers under the auspices of the AFL, despite the hostile legal environment so well described by historians of labor and the law. This fact does not necessarily contradict their arguments, since most of these scholars use the character of the law to analyze the origins of the AFL's politics. By 1917 the Flat Janitors had not even entered the traditional political arena, although they soon would. The history of the Flat Janitors even supports the argument of William Forbath and others that the pervasive impact of the law on unions profoundly shaped the way labor leaders thought, leading them to use legal language to frame their goals and policies. ${ }^{64}$ Quesse's use of terms like grievances to articulate the union's opposition to the Marshalls was one piece of evidence for that. On the other hand, the history of the Flat Janitors sends cautionary signals about the current state of research, the definition of business unionism, and the explanatory power of the law in interpreting the history of labor.

Practically all of the discussion of labor and the law during the progressive era concerns national, and to some extent, state affairs and institutions. The legal conflicts of the Flat Janitors, however, took place almost exclusively in the Circuit Court of Cook County, which, of course, had its own history--the kind that needs to be brought into the discussion if the subject of labor and the law is to be adequately addressed. Despite being on the local governmental level, the courts of Cook County constituted one of the largest judicial systems in the country. ${ }^{65}$

The history of the Flat Janitors also suggests that the definition of business unionism should be expanded. Most current discussion of labor and the law conflates business unionism and the AFL's voluntarist political position. Explaining the latter presumably accounts for the former as well. Yet the Flat Janitors distinctive role in the metropolitan economy was central to its version of business unionism. After the 1917 contract the Flat Janitors and the Real Estate Boards 
contained their hostility sufficiently to manage the metropolitan real estate industry to their respective advantages. That common effort at market management--from the bottom up and the top down--formed the core of the Flat Janitors' business unionism, not voluntarist politics.

Most important, the history of the Flat Janitors illustrates how the union's economic role helped it survive its legal status of "semioutlawry," in William Forbath's terms. ${ }^{66}$ The dominant group of real estate owners even marginalized the union's main legal opponent in an effort to achieve a favorable contract. This point supports the general line of argument pursued by David Brody and Melvyn Dubofsky--that the contemporary structures of economic and political power were most decisive in shaping the history of the labor movement, as well as the law. The Flat Janitors' history indicates that the current debate on labor and the law has concentrated too much on the state and too little on the economy. The state has indeed been "brought back in," and the economy should be as well.

\section{Endnotes}

1. For introductions to contemporary scholarship on labor and the law see Christopher L. Tomlins and Andrew J. King, "Introduction: Labor, Law, and History," in Labor Law in America: Historical and Critical Essays (Baltimore: The Johns Hopkins University Press, 1992), 1-19; Christopher Tomlins, "How who rides whom. Recent 'new' histories of American labour law and what they may signify," Social History 20, no. 1 (January 1995): 1-21.

For interpretations of the emergence of business unionism by legal historians see Christopher L. Tomlins, The State and the Unions: Labor Relations, Law, and the Organized Labor Movement in America, 18801960 (Cambridge, England: Cambridge University Press 1985); William E. Forbath, Law and the Shaping of the American Labor Movement (Cambridge, MA: Harvard University Press, 1991); Victoria C. Hattam, Labor Visions and State Power: The Origins of Business Unionism in the United States (Princeton: Princeton University Press, 1993).

For claims about the larger explanatory power of the law in American labor history see Forbath, ix-xiii, 1-9, 167-73; Christopher L. Tomlins, "Law: the modality of rule," chap. in Law, Labor, and Ideology in the

Labor History, Vol. 38, No. 4 (Fall, 1997): pg. 413-431. DOI. This article is (c) Taylor \& Francis (Routledge) and permission has been granted for this version to appear in e-Publications@Marquette. Taylor \& Francis (Routledge) does not grant permission for this article to be further copied/distributed or hosted elsewhere without the express permission from Taylor \& Francis (Routledge). 
NOT THE PUBLISHED VERSION; this is the author's final, peer-reviewed manuscript. The published version may be accessed by following the link in the citation at the bottom of the page.

Early American Republic (Cambridge, England: Cambridge University Press, 1993), 19-34; Tomlins, "How who rides whom."

2. Melvyn Dubofsky, review of The State and the Unions, by Christopher L. Tomlins, Law and History Review 4 (1986): 472; Melvyn Dubofsky, review of Law and the Shaping of the American Labor Movement, by William E. Forbath, Industrial and Labor Relations Review 5 (1992): 10; "Review Symposium" on Forbath's Law and the Shaping of the American Labor Movement including comments by Dubofsky, Nick Salvatore, and Ellen Fitzpatrick in Industrial and Labor Relations Review 45, no. 4 (July 1992): 806-13; Melvyn Dubofsky, The State and Labor in Modern America (Chapel Hill: University of North Carolina Press, 1994); David Brody, review of Law, Labor and Ideology in the Early American Republic, by Christopher L. Tomlins, International Labor and Working-Class History no. 47 (Spring 1995): 144-47. In 1995 Brody's review provoked a debate on the Listserv $\mathrm{H}$ Labor in which Tomlins and Dubofsky, among others, participated. For a useful review of the history of this whole debate see Daniel R. Ernst, "Picking Up the Pieces," review of The State and Labor in Modern America, by Melvyn Dubofsky, Reviews in American History 23, no. 3 (September 1995): 502-09.

Both Brody and Dubofsky, of course, have written about the economic dimension of labor history, but the current debate about labor and the law has structured discussion almost exclusively around politics and the state.

3. Chicago Commission on Race Relations, The Negro in Chicago: A Study of Race Relations and a Race Riot (Chicago: University of Chicago, 1922), 415-16. For a discussion of the Flat Janitor's policy on racial and ethnic prejudice see John B. Jentz, "Citizenship, Self-Respect, and Political Power: Chicago's Flat Janitors Trailblaze the Service Employees International Union, 1912-1921," Labor's Heritage, 9 (Summer 1997), 4-23.

4. AFL-CIO Department of Organization and Field Services, International and National Unions, Charter Files, Box 1, International Union of Building Employees of America, The George Meany Memorial Archives, Silver Spring, Maryland (hereafter Meany Archives); Tom Beadling, Pat Cooper, Grace Palladino, A Need for Valor: The Roots of the Service Employees International Union 1902-1980 (Washington, D.C.: Service Employees International Union, n.d.), 5-6.

5. Entries on "Industrial Unionism" and "Unskilled Labor" in American Federation of Labor (hereafter AFL), History, Encyclopedia Reference Book (Washington, D.C.: AFL, 1919), 246- 48, 396-97; Nick has been granted for this version to appear in e-Publications@Marquette. Taylor \& Francis (Routledge) does not grant permission for this article to be further copied/distributed or hosted elsewhere without the express permission from Taylor \& Francis (Routledge). 
NOT THE PUBLISHED VERSION; this is the author's final, peer-reviewed manuscript. The published version may be accessed by following the link in the citation at the bottom of the page.

Salvatore, Eugene V. Debs: Citizen and Socialist (Urbana: University of Illinois Press, 1982), 203-11.

6. Kidd quoted in Samuel Gompers to the members of the AFL Executive Council, 10 August 1905, Executive Council Vote Books (May to October 1905), Meany Archives; AFL, Proceedings of the Twenty-Fifth Annual Convention (1905) (Washington, D.C.: The Law Reporter Printing Company, 1905), 62.

7. On the teamsters strike of 1905 see Illinois, State Board of Arbitration, Tenth Annual Report (1905) (Springfield: Phillips Bros., State Printers, 1906), 28-34; Georg Leidenberger, "'The Public is the Labor Union': Working-Class Progressivism in Turn-of-the-Century Chicago," Labor History 36, no. 2 (Spring 1995): 187-210. Leidenberger is excellent on the successful Chicago organizing campaign in the early twentieth century as well as on the centrality of the teamsters to it. The alliance between the teamsters and the janitors is discussed below.

8. Flat Janitors Local 12361 was chartered in 1906 and still survived in 1912; American Federation of Labor, Charter Books of Local Unions, Vol. 3, Meany Archives; Frank McWatters, speech, "Proceedings, Building Service Employees International Union, May 1, 1928, Bismark Hotel, Chicago, Ill.," (hereafter BSEIU Proceedings 1928) Archives, Service Employees International Union, Washington, D.C. (hereafter SEIU Headquarters), 75. Flat Janitors Local 13074 also existed in 1912, probably on Chicago's North Side; AFL, List of Organizations Affiliated with the American Federation of Labor. . . June 24, 1912

(Washington, D.C.: The Trades Unionist Print, 1912), 35; AFL, Charter Book, Vol. 3, Meany Archives. Kaspar Thegen, then head of this local, challenged Quesse's leadership of Local 14332 in 1915; see below.

9. [William F. Quesse], "To the Public: Tenants of Apartment Buildings in Particular, as well as Landlords and Real Estate Agents," Archives, Local 1, Service Employees International Union, Chicago, Illinois (hereafter Local 1), 3.

10. In the earliest negotiations between Local 14332 and the Chicago Board of Real Estate Quesse asked for a ban on janitors doing the work of construction trades, although he did not get it. Building trades unions complained to the Chicago Federation of Labor in 1914 about janitors doing construction work; but these complaints ceased the next year; apparently some accommodation had been reached. See the Chicago Federation of Labor's minutes published as broadsides (hereafter CFL Broadside Minutes), Chicago Federation of Labor Papers, Chicago

Labor History, Vol. 38, No. 4 (Fall, 1997): pg. 413-431. DOI. This article is (c) Taylor \& Francis (Routledge) and permission has been granted for this version to appear in e-Publications@Marquette. Taylor \& Francis (Routledge) does not grant permission for this article to be further copied/distributed or hosted elsewhere without the express permission from Taylor \& Francis (Routledge) 
NOT THE PUBLISHED VERSION; this is the author's final, peer-reviewed manuscript. The published version may be accessed by following the link in the citation at the bottom of the page.

Historical Society (hereafter CFL Papers), 16 March 1913, 15 November and 6 December 1914.

11. Superior Court of Cook County, Bill for Injunction, Marshall v. Chicago Flat Janitors' Union, Case No. 313149, December 1914, Clerk of the Circuit Court of Cook County Archives, Chicago, Illinois (hereafter Marshall v. Flat Janitors), p. 17.

12. During a strike in 1914 and 1915 tenants in struck buildings could not get service from new suppliers because the businesses feared "trouble" with their own union teamsters. Such cooperative policies by union janitors and teamsters effectively regulated market share among suppliers to tenants. See Affidavit of C. J. Ilgen, Marshall v. Flat Janitors.

13. "District Manager Gus Anderson," Public Safety (SEIU Headquarters) 9, no. 1 (January 1937): 17-18.

14. In 1915 Quesse estimated that the number of employers for each flat janitor ranged from one to ten, giving the union "more employers to combat than all other labor organizations in the city combined;" William F. Quesse and C. R. Rowens to "Gentlemen" at the AFL in Washington D.C., 27 January 1915, CFL papers, box 3, folder 18. The typical flat janitor had more than one employer.

15. Ibid., 18.

16. Richard Schneirov and Thomas J. Suhrbur, Union Brotherhood, Union Town: The History of the Carpenters' Union of Chicago 1863-1987 (Carbondale, IL: Southern Illinois University Press, 1988), 34. There is a good discussion of the closed shop in the building trades in William Haber, Industrial Relations in the Building Industry (Cambridge: Harvard University Press, 1930), 238-43. The janitors drew their model for arbitrating disputes from the building trades.

17. The classic statement of this rationale is [Quesse], "History of the Organization," 1916 Yearbook, n. p.

18. In interviews with the author, Dino Pigoni, President of Local 1, and Eugene P. Moats, President of Local 25, discussed their personal experiences of prejudice against the children of janitors.

19. Chicago. Department of Health. Chicago School of Sanitary Instruction, Bulletin 8, no. 3 (New Series; 17 January 1914): 12.

20. The classic statement of the conditions under which the janitors lived and worked is [William F. Quesse], "History of the Organization: Why and How the Flat Janitors of Chicago, Illinois Were Organized," in Official

Labor History, Vol. 38, No. 4 (Fall, 1997): pg. 413-431. DOI. This article is (c) Taylor \& Francis (Routledge) and permission has been granted for this version to appear in e-Publications@Marquette. Taylor \& Francis (Routledge) does not grant permission for this article to be further copied/distributed or hosted elsewhere without the express permission from Taylor \& Francis (Routledge). 
Year Book (1916) (Chicago: Chicago Flat Janitors' Union Local No. 14332, 1916), Archives, Local 1, no page numbers; for the last quote see "William F. Quesse With His Stub Pencil and Pad of Paper," Public Safety 3, no. 15 (July 1931): 11.

21. "District Manager Gus Anderson," 18.

22. William C. Quesse, Jr., "District Manager Carries on in Union His Father Organized," Public Safety, 8, no. 3 (July 1936): 10; see also "History of Chicago Flat Janitors No. 1," Public Safety 1, no. 1 (1 October 1929): 23

23. Superior Court of Cook County, Declaration, Case No. 13S305393, William F. Quesse v. Franklin Hardin and Ella M. Hardin, December 1913, Clerk of the Circuit Court of Cook County Archives, Chicago, Illinois.

24. Bill for Injunction, Marshall v. Flat Janitors, pp. 49-51; see also the affidavit of A. E. Matthews, Manager of the Apartment Buildings Association, attached to this Bill.

25. Who's Who in Chicago 1926: The Book of Chicagoans (Chicago: A. N. Marquis \& Co., 1926).

26. Affidavit of Peter Assem, Marshall v. Flat Janitors.

27. Affidavit of John E. Kunke, Marshall v. Flat Janitors.

28. Bill for Injunction, Marshall v. Flat Janitors, p. 19; also affidavits of Lilian E. J. Michelet and C. J. Ilgen, same case.

29. Affidavit of Tillie Assem, Marshall v. Flat Janitors.

30. Bill for Injunction, Marshall v. Flat Janitors, pp. 36-37; affidavit of Thomas Delaney, same case.

31. Affidavit of Mrs. Edith C. They, Marshall v. Flat Janitors.

32. Affidavits of John Mahin and C. J. Ilgen, Marshall v. Flat Janitors.

33. Affidavit of Mrs. J. P. Strickland, Marshall v. Flat Janitors.

34. Affidavit of Mrs. E. A. Stratton, Marshall v. Flat Janitors.

35. Bill for Injunction, Marshall v. Flat Janitors, pp. 20-21, 27-28.

36. Bill for Injunction, Marshall v. Flat Janitors, pp. 22-25, 37-38.

37. Affidavit of John E. Kunke, Marshall v. Flat Janitors.

38. At the 1928 convention of the Building Service Employees' International Union, Oscar Nelson, then president of the International,

Labor History, Vol. 38, No. 4 (Fall, 1997): pg. 413-431. DOI. This article is (c) Taylor \& Francis (Routledge) and permission has been granted for this version to appear in e-Publications@Marquette. Taylor \& Francis (Routledge) does not grant permission for this article to be further copied/distributed or hosted elsewhere without the express permission from Taylor \& Francis (Routledge) 
acknowledged the use of sabotage by the flat janitors in the early days of organizing: BSEIU Proceedings 1928, p. 40. On violence from both sides in Chicago building trades' strikes see Schneirov and Suhrbur, 80-81, 104-05. A committee of the Chicago Common Council reported on violence by police and private guards in a 1915 garment workers' strike: Journal of the Proceedings of the City Council of the City of Chicago for the Council Year 1915-1916, vol. I, 1789-1792. For accusations of violence against both sides in a 1917 office janitors' strike see: John Dorr Bradley to John Fitzpatrick, 14 March 1917, CFL Papers, box 5, folder 37; Report of Delegate Sims, CFL Broadside Minutes, CFL Papers, 18 February 1917.

39. Order for Injunction, Marshall v. Flat Janitors. The case ended in 1918 by mutual agreement between both sides with no damages paid by either one; Stipulation and subsequent Order, Marshall v. Flat Janitors, October 1918.

40. Forbath, 60-62, 82-84, 88-91; see also Hattam, 162-64.

41. Samuel Gompers to John Fitzpatrick, 2 March 1915, CFL Papers, box 3, folder 20.

42. Foster Rhea Dulles and Melvyn Dubofsky, Labor in America: A History, Fourth Edition (Arlington Heights, IL: Harlan Davidson, Inc., 1984), 194-195; Forbath, 156-57; Hattam, 163-64.

43. CFL Broadside Minutes, 16 July 1916. In 1916 the Illinois Federation of Labor made state legislation limiting the use of injunctions against unions the center of its political program; CFL Broadside Minutes, 4 June 1916; Chicago Herald, 12 January 1917; Republican (Chicago), 14 April 1917.

44. Bill for Injunction, Marshall v. Flat Janitors, pp. 41-46; quote on p. 46.

45. Bill for injunction, Marshall v. Flat Janitors, pp. 47-50.

46. Christopher L. Tomlins, The State and the Unions: Labor Relations, Law, and the Organized Labor Movement in America, 1880-1960 (Cambridge, England: Cambridge University Press, 1985), 60-67.

47. Affidavit of A. B. Matthews attached to Bill for Injunction, Marshall v. Flat Janitors.

48. Forbath, 135-36.

49. B. M. Carra to Governor Len Small, 31 December 1923, filed with Illinois Parole and Pardon Board, "William F. Quesse, et al.," Record Series 403.2, Illinois State Archives (hereafter Pardon Hearings).

Labor History, Vol. 38, No. 4 (Fall, 1997): pg. 413-431. DOI. This article is (c) Taylor \& Francis (Routledge) and permission has been granted for this version to appear in e-Publications@Marquette. Taylor \& Francis (Routledge) does not grant permission for this article to be further copied/distributed or hosted elsewhere without the express permission from Taylor \& Francis (Routledge). 
NOT THE PUBLISHED VERSION; this is the author's final, peer-reviewed manuscript. The published version may be accessed by following the link in the citation at the bottom of the page.

50. Oscar Nelson, testimony, official transcript, Pardon Hearings, p. 35.

51. Colin Gordon, New Deals: Business, Labor, and Politics in America, 19201935 (Cambridge: Cambridge University Press, 1994), 87. See his whole Chapter 3, "Workers Organizing Capitalists: Regulatory Unionism in American Industry, 1920-1932," 87-127.

52. Pat Cooper, "History of the Building Service Employees International Union," Typescript, SEIU Headquarters, p. 9.

53. The estimate of about 3,000 in 1915 is based on Circuit Court of Cook County, Bill for Injunction, George Gough v. Chicago Flat Janitors' Union (hereafter Gough v. Flat Janitors), Case No. 15C014238, September 1915, Clerk of the Circuit Court of Cook County Archives, Chicago, Illinois. The estimate of about 6,000 by 1917 is based on \{Quesse], "History of the Organization," 1916 Yearbook, n. p.; Frank Morrison to John Fitzpatrick, 1 September 1917, CFL Papers, box 6, folder 41 . The federal census of 1920 counted 9,375 male janitors in Chicago, but did not break down them down by type of janitor; Bureau of the Census, Fourteenth Census of the United States (1920), vol. 4: Population 1920. Occupations (Washington: GPO, 1923), 1079. Given the large number of apartment buildings compared to office buildings, it is reasonable to assume that perhaps two-thirds to three-fourths of the 1920 total were flat janitors. The total of around 6,000 members would give the union effective control of the labor market in its industry.

54. Superior Court of Cook County, Bill of Complaint, Kaspar Thegen, et al. v. William T. [sic.] Quesse, et al., Case No. 318128, September 1915, Clerk of the Circuit Court of Cook County Archives, Chicago, Illinois. On subsequent battles with Thegen see CFL Broadside Minutes, 5 March 1916.

55. Bill for Injunction, Gough v. Flat Janitors.

56. Quesse and to "Gentlemen," 27 January 1915, CFL Papers.

57. [William F. Quesse], "History of the Organization: Why and How the Flat Janitors of Chicago, Illinois were Organized," Official Year Book Published by Chicago Flat Janitors' Union Local No. 14332 (1919) (Chicago: The Star Printing Co., 1919), 31-33.

58. "District Manager Gus Anderson," 18.

59. Chicago Tribune, 7, 8, 10, 17, 18, 21, 24 January 1917; Chicago Herald, 20 Jan 1917.

Labor History, Vol. 38, No. 4 (Fall, 1997): pg. 413-431. DOI. This article is (c) Taylor \& Francis (Routledge) and permission has been granted for this version to appear in e-Publications@Marquette. Taylor \& Francis (Routledge) does not grant permission for this article to be further copied/distributed or hosted elsewhere without the express permission from Taylor \& Francis (Routledge). 
NOT THE PUBLISHED VERSION; this is the author's final, peer-reviewed manuscript. The published version may be accessed by following the link in the citation at the bottom of the page.

60. Chicago Tribune, 13, 17 January 1917; [Quesse], "History of the Organization," 31-33.

61. [Quesse], "To the Public," 4.

62. Chicago Herald, 16 January 1917; "Agreement and Wage Scale of the Chicago Flat Janitors' Union" (1917), Local 1.

63. Chicago Herald, 18 January 1917; CFL Broadside Minutes, 18 February, 4 March, 15 April 1917; John Fitzpatrick and E. Nockels to John Dorr Bradley, 17 February 1917, Box 5, Folder 37, CFL Papers; John Fitzpatrick to Carpenters' District Council, et al., n. d., Box 5, Folder 37, CFL Papers.

64. Forbath, 6-8; 169-73.

65. Albert Lepawsky, The Judicial System of Metropolitan Chicago (Chicago: University of Chicago Press, 1932), 2-3, 126-27, 166-68.

66. Forbath, $98 \mathrm{ff}$. has been granted for this version to appear in e-Publications@Marquette. Taylor \& Francis (Routledge) does not grant permission for this article to be further copied/distributed or hosted elsewhere without the express permission from Taylor \& Francis (Routledge). 